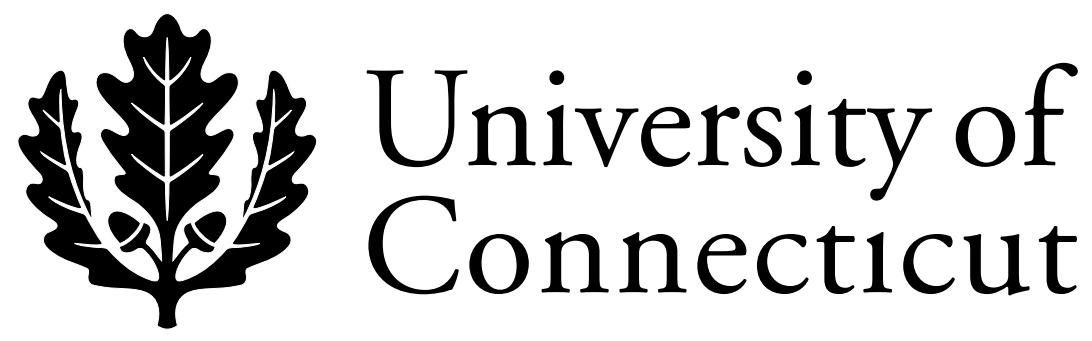

Department of Economics Working Paper Series

\title{
Time-Limited Property Rights and Investment Incentives
}

Thomas J. Miceli

University of Connecticut

C. F. Sirmans

University of Connecticut

Working Paper 2003-39

July 2003

341 Mansfield Road, Unit 1063

Storrs, CT 06269-1063

Phone: (860) 486-3022

Fax: (860) 486-4463

http://www.econ.uconn.edu/ 


\begin{abstract}
Although it is axiomatic that property rights of infinite duration are necessary for owners to make efficient long term investments in their property, time limits on property rights are pervasive in the law. This paper provides an economic justification for such limits by arguing that they actually enhance property values in the presence of various sorts of market failure. The analysis offers a coherent approach for understanding what otherwise appear to be unrelated doctrines in the law.
\end{abstract}




\section{Time-limited Property Rights and Investment Incentives}

In his excellent survey paper, Geoffrey Turnbull uses a dynamic investment framework to examine the effects of various land use regulations on the timing and pattern of land development in an urban setting. By emphasizing the dynamic effects of land use policies, Turnbull uncovers important new insights into nature of land development. However, because his focus is on the incentive effects of various regulations (actual or threatened), he devotes little attention to the economic rationale behind those regulations. This essay extends Turnbull's analysis by highlighting the social benefits of a certain class of restrictions that take the form of time-limited property rights. Our specific contribution is to use Turnbull's dynamic investment framework to reveal the common economic logic underlying this type of restriction.

It is axiomatic in economics that property rights of infinite duration are necessary for owners to make efficient long term investments in their property. Yet legally imposed time limits on property rights are pervasive in the law (Epstein, 1986). One example, mentioned by Turnbull, is the law of adverse possession, which establishes a statute of limitation on a landowner's right to exclude squatters or boundary encroachers from their land. If the landowner does not assert that right before the statutory period expires, title passes to the adverse possessor. Although many have argued that this rule seems to legalize theft, the existence of adverse possession statutes in all fifty states suggests that there is a compelling economic reason for limiting property rights in this way. We show that it can in fact be seen as an efficient means of balancing offsetting risks to ownership in a world of imperfect information. 
The general lesson from this, and the other examples that we will analyze, is that time-limited property rights, rather than diluting the social value of property, can actually increase it. Further, the dynamic investment model offers a coherent approach to understanding what otherwise appear to be unrelated doctrines in the law.

\section{Adverse Possession Statutes}

As noted, all fifty states have adverse possession statutes that limit the duration of landowner's exclusive right of possession. ${ }^{1}$ In a world of imperfect information, timelimited property rights for land balance two offsetting risks to landowners. ${ }^{2}$ The first risk concerns claims from past owners who were deprived of their property through fraud or error. Time-limited property rights represent a statute of limitations on such claims--the longer is the statute length, the greater is the risk of a claim materializing at any point in time. To capture this formally, let $p(t)$ be the probability of a claim against a current possessor, where $t$ is the duration of the prior owner's property right, and $p>0$, reflecting a higher current risk for a longer lasting property right. We also assume that $p(0)=0{ }^{3}$

The other risk facing the current owner is that he can himself be the victim of expropriation due to fraud or error, especially if he is an absentee owner. Such a loss can be avoided, however, by periodically monitoring the property to expel squatters or boundary encroachers, or to correct errors in the public record. A longer duration of the owner's property right saves on such costs by reducing the frequency of monitoring needed to enforce this exclusive right. To capture this risk, let $m(t)$ be the monitoring

\footnotetext{
${ }^{1}$ The duration varies considerably by state, ranging from five to forty years. See Baker, et al. (2001) and Netter, Hersch and Manson (1986) for empirical analyses that explain the cross-state variation.

${ }^{2}$ See Baird and Jackson (1984) for a general discussion of land conveyance in a world of uncertain ownership.

${ }^{3}$ The Torrens system of land registration, which is the prevailing system in England, and has been used in some jurisdictions in the U.S., effectively sets $t=0$, meaning that past errors do not entitle claimants to re-
} 
costs the owner must expend to maintain ownership with certainty, where $m^{\prime}<0$, and $m(\infty)=0$.

Current landowners make investment decisions, taking the duration of property rights as given. Let $V(x)$ be the value of developed land, where $x$ is the dollar investment, and $V>0, V^{\prime \prime}<0$. If property rights were certain, the optimal investment would maximize $V(x)-x$. Given uncertainty, however, owners will choose $x$ to maximize

$$
(1-p(t)) V(x)-x-m(t)
$$

where $1-p(t)$ is the probability that they will retain property rights to their land. The first-order condition defining the optimal investment, $x^{*}(t)$, is

$$
(1-p(t)) V^{\prime}(x)-1=0
$$

Totally differentiating (2) shows that

$$
\frac{\partial x^{*}}{\partial t}=\frac{V^{\prime} p^{\prime}}{(1-p) V^{\prime \prime}}<0
$$

Thus, property rights of longer duration actually reduce investment incentives by increasing the risk that a past claim will be asserted against the current owner.

Given the preceding characterization of rational landowner behavior, we now derive the socially optimal duration of property rights to land. This is the value of $t$ that maximizes the value of the land net of monitoring costs, given the owner's optimal investment function:

$$
V\left(x^{*}(t)\right)-x^{*}(t)-m(t)
$$

acquire their land. Instead they can seek monetary compensation from a pubic fund. See Miceli, et al. (2002) and Janczyk (1977) for formal analyses, and Shick and Plotkin (1978) for a historical discussion. ${ }^{4}$ The assumption that owners retain their property with certainty by spending $m(t)$ is made purely for simplicity and does not affect our basic conclusions. 
(Note that $p(t)$ does not enter this expression because the social value of the land is independent of ownership, once $x$ has been chosen.) The optimal $t$ solves the first-order condition

$$
\left(V^{\prime}-1\right)\left(\partial x^{*} / \partial t\right)-m^{\prime}=0 .
$$

After substituting from (2), this becomes:

$$
p V^{\prime}(\partial x * / \partial t)=m^{\prime}
$$

This expression captures the basic trade-off between the two risks facing landowners, as described above. The left-hand side reflects the reduced investment incentive as $t$ is lengthened, owing to the risk from past claims. At the optimum, this is balanced against the savings in monitoring costs as $t$ is lengthened. Generally, (6) implies that a finite duration of property rights in land is optimal.

\section{Mortgage Redemption Statutes}

Mortgage redemption statutes establish a period of time following mortgage default during which the mortgagor (borrower) can reclaim the property by paying off the loan balance. Such statutes have a long history in Anglo-American law, and although the trend appears to be toward abandoning them, several states still have redemption statutes on the books (Jaffe and Sharp, 1996). As of 1995, for example, seventeen states had redemption statutes, ranging in length from one to twelve months. The fact that the extension is statutory makes it a default provision in all loans; the question here is whether such a provision promotes efficiency by enhancing the value of mortgage contracts.

Consider a mortgage that obligates the borrower to pay an amount $B$ (principal plus interest) at a contractually set time. There is some risk that the borrower will 
default, but he can reduce that probability by investing in effort $x$ (measured in dollars) prior to the due date. Let $p(x)$ be the probability that he will not default, where $p^{\prime}>0$ and $p^{\prime \prime}<0$.

Suppose the borrower values the mortgaged property at $V$, while its market value is $M$. Further, suppose that $V>B>M$. Thus, sale of the property cannot forestall default, but the borrower attaches sufficient value to the property that he does not want to abandon it in lieu of paying off the loan. For residential property, the difference $V-M$ reflects the owner's "subjective value," possibly arising from his attachment to the land, while for commercial property, it might reflect goodwill or the utility benefits associated with a family business (Hart, 1995).

To capture the impact of a redemption statute, let $q(t)$ be the probability that the borrower is able to redeem the property, conditional on default, where $t$ is the length of the redemption period. Thus, $q>0, q(0)=0$, and $q(\infty)=1$. The borrower takes the redemption period as given and chooses his investment in effort, $x$, to maximize his expected net value of the property:

$$
[p(x)+(1-p(x)) q(t)](V-B)-x
$$

The expression in square brackets is the probability that the borrower retains possession, while $V-B$ is his net value after paying off the loan. The first-order condition for $x *(t)$ is

$$
p^{\prime}(1-q(t))(V-B)-1=0
$$

Totally differentiating this condition yields

$$
\frac{\partial x^{*}}{\partial t}=\frac{p^{\prime} q^{\prime}}{p^{\prime \prime}(1-q)}<0
$$


which says that, as the redemption period is lengthened, the borrower invests less effort in avoiding default.

To show the offsetting benefit of a redemption period, we write the expected social value of the property as

$$
[p(x *(t))+(1-p(x *(t))) q(t)] V+\left(1-p\left(x^{*}(t)\right)\right)(1-q(t) M-x *(t)
$$

where the first term is the value if the borrower retains possession, and the second is the value if the property must be sold. Note that the amount of the loan does not enter this expression since it is just a transfer payment. Re-arranging this expression yields

$$
=M+[p(x *(t))+q(t)-p(x *(t)) q(t)](V-M)-x *(t)
$$

The optimal redemption period is found by maximizing (10), which yields the first-order condition

$$
\left[p^{\prime}(1-q)(V-M)-1\right](\partial x * / \partial t)+(1-p) q^{\prime}(V-M)=0
$$

After substituting from (8) and rearranging, this becomes

$$
-p^{\prime}(1-q)(B-M)\left(\partial x^{*} / \partial t\right)=(1-p) q^{\prime}(V-M)
$$

The left-hand side of this condition reflects the disincentive effect on borrowers of lengthening the redemption period. The resulting increase in the probability of default imposes a loss of $B-M$ on lenders if redemption fails to occur. Offsetting this is the expected gain from a longer $t$, which is given by the greater likelihood that the borrower will retain the property and realize his subjective value. According to this model, therefore, the redemption period should be longer for properties with greater subjective value, for example residential property and family farms (Alston, 1984). 


\section{The Rule Against Perpetuities}

Bequests represent an important mechanism for the transfer of property from one generation to the next. Wills, like mortgages, are largely consensual, but historically, the law has placed certain limitations on the discretion of testators regarding the disposal of their property. We consider here a rule that, while famously confusing, remains a vital part of Anglo-American inheritance law--namely, the rule against perpetuities. Simply stated, the rule places a time limit on restrictions that testators can impose on the uses of their estates (so-called "dead hand" controls). An economic rationale for this limit on the alienability of assets across generations closely parallels the analysis in the preceding sections, and therefore can be examined within a similar framework. ${ }^{5}$

Consider a property owner who can invest in the expansion and maintenance of his estate during his lifetime. Let $R(x, t)$ be the owner's personal return from this effort, where $x$ is the dollar investment, and $t$ is the period of time over which he can impose binding controls on the uses of his estate after his death. We assume that $R_{x}>0$ and $R_{x x}<0$, reflecting diminishing marginal benefits from the investment, while $R_{t}>0$, reflecting the satisfaction the owner gets, both from imposing his preferences on the use of the property in the future, and from protecting it against prodigal heirs. Finally, we assume that $R_{x t}>0$, which says that the marginal benefit of investment increases with the length of the testator's control over the estate.

The owner's problem during his lifetime is to choose the level of investment $x$ to maximize

$$
R(x, t)-x
$$

taking $t$ as given. The first-order condition defining the optimal investment, $x *(t)$, is 


$$
R_{x}(x, t)-1=0
$$

From which it follows that

$$
\frac{\partial x^{*}}{\partial t}=\frac{R_{x t}}{-R_{x x}}>0
$$

Thus, the longer is the period of testators' control, the greater is their incentive to invest in the accumulation of wealth in their lifetimes.

Counteracting this, however, is the cost of increasing the period during which the testator can restrict the uses of the estate, which arises from the inability of inheritors to respond to changing circumstances that were unforeseeable to the testator. To capture this factor, let $V(x, t)$ be the present value of the estate to all future inheritors (i.e., all owners beyond the testator), where $V_{x}>0$, reflecting the value of the original owner's investment, but $V_{t}<0$, reflecting the cost of inflexibility. ${ }^{6}$

We can now characterize the social problem as choosing $t$ to maximize the overall present value of the estate:

$$
R(x *(t), t)+V(x *(t), t)-x *(t),
$$

taking as given the owner's optimal choice of $x$. The first-order condition is

$$
\left(R_{x}+V_{x}-1\right)(\partial x * / \partial t)+R_{t}+V_{t}=0
$$

Substituting from (13) and rearranging yields

$$
V_{x}(\partial x * / \partial t)+R_{t}=-V_{t}
$$

The left-hand side reflects the marginal benefit of lengthening $t$, consisting of the incentive effect on the testator's choice of $x$ plus his direct benefit from greater control

\footnotetext{
${ }^{5}$ The analysis formalizes the discussion of the rule against perpetuities in Ellickson (1986, pp. 734-737).

${ }^{6}$ It may be the case that $V_{t}>0$ for small $t$, reflecting the value of restricting the actions of heirs that the testator knows to be wasteful, but as $t$ increases into the unknown future, the cost of inflexibility will eventually dominate.
} 
over the estate. At the optimum, this just equals the marginal cost of increasing $t$ in terms of the reduced ability of future owners to respond to changing circumstances.

\section{Intellectual Property}

The preceding examples have focused primarily on time-limited property rights in real property, but the law also sets a limit on exclusive ownership of intellectual property, or ideas. Specifically, patent law awards exclusive rights to inventors, usually for seventeen years, while copyright law gives exclusive rights to authors for the author's life plus fifty years. The basic trade-off underlying limited property rights in ideas is wellknown in the literature: ${ }^{7}$ legally protected property rights are needed to guarantee financial incentives for the creation of inventions or original works of art, but such rights are limited in order to assure wide access to the ideas contained in these works. On its face, this trade-off seems quite different from that underlying limited property rights in land, but the following analysis reveals a common economic logic.

To illustrate, let $R(t)$ be the present value of the rents that the creator of an idea can earn given a legally protected property right (monopoly) lasting $t$ years, where $R>0$ and $R(0)=0$ (due to competition). At the same time, let $S(t)$ be the social value of the idea, where $S(t)>R(t)$ for all $t$, reflecting the deadweight loss from monopoly pricing by the creator. ${ }^{8}$ Further, since the social value of an idea is maximized by the shortest possible patent duration, $S^{\prime}<0$.

The preceding implies that property rights inhibit the widespread use of an idea, and hence are socially undesirable, but that presumes existence of the idea. As noted, exclusive property rights are essential to reward the inventive efforts of the creator. To

\footnotetext{
${ }^{7}$ On patents, see Kitch (1977) and on copyrights see Landes and Posner (1989).
} 
capture this incentive function, let $p(x)$ be the probability that an investment of $x$ dollars will yield a fruitful idea, where $p>0$ and $p^{\prime \prime}<0$. Given $t$, the would-be creator will choose $x$ to maximize his expected private return:

$$
p(x) R(t)-x \text {. }
$$

This yields the first-order condition

$$
p R(t)-1=0,
$$

which defines the optimal investment, $x *(t)$. Totally differentiating (19) yields

$$
\frac{\partial x^{*}}{\partial t}=\frac{-p^{\prime} R^{\prime}}{p^{\prime \prime} R}>0 .
$$

Thus, property rights of greater duration provide stronger incentives to create socially valuable ideas.

Given the incentives of creators, the social problem is to choose the duration of property rights in ideas to maximize the expected social return from the idea:

$$
p\left(x^{*}(t)\right) S(t)-x^{*}(t) .
$$

The resulting first-order condition is

$$
(p S-1)(\partial x * / \partial t)+p S^{\prime}=0 .
$$

After substituting from (19), this becomes

$$
p^{\prime}(S-R)\left(\partial x^{*} / \partial t\right)=-p S^{\prime}
$$

The left-hand side reflects the net social gain from greater inventive effort as the duration of property rights is increased. At the optimum, this just equals the expected loss in social value resulting from the increase in monopoly power extended to the originator.

\footnotetext{
${ }^{8}$ It also reflects the transaction costs involved in the negotiation of licensing agreements (if any) between the creator and would-be users of the idea.
} 


\section{Conclusion}

Turnbull emphasized the effect of property restrictions on investment incentives in a dynamic context. In this paper, we focused on restrictions that take the form of timelimited property rights. Such restrictions are pervasive in the law, and economic theory helps to explain why. While time-limits tend to inhibit owners' incentives to make long term investments, they often produce offsetting social benefits. The nature of these benefits varies depending on the type of property in question, but we have shown that an economic approach centering on dynamic investment incentives reveals a common underlying logic. 


\section{References}

Alson, Lee J. (1984) "Farm Foreclosure Moratorium Legislation: A Lesson from the Past," American Economic Review 74: 445-457.

Baird, Douglas and Thomas Jackson (1984) "Information, Uncertainty, and the Transfer of Property," Journal of Legal Studies 13: 299-320.

Baker, Matthew, Thomas J. Miceli, C.F. Sirmans, and Geoffrey Turnbull (2001)

"Property Rights by Squatting: Land Ownership Risk and Adverse Possession Statutes," Land Economics 77: 360-370.

Ellickson, Robert (1986) "Adverse Possession and Perpetuities Law: Two Dents in the Libertarian Model of Property Rights," Washington University Law Quarterly 64: 723758.

Epstein, Richard (1986) "Past and Future: The Temporal Dimension in the Law of Property," Washington University Law Quarterly 64: 667-722.

Hart, Oliver (1995) Firms, Contracts, and Financial Structure, New York: Oxford Univ. Press.

Jaffe, Austin and Jeffery Sharp (1996) "Contract Theory and Mortgage Foreclosure Moratoria," Journal of Real Estate Finance and Economics 12: 77-96.

Janczyk, Joseph (1977) "An Economic Analysis of the Land Title Systems for Transferring Real Property,” Journal of Legal Studies 6: 213-233.

Kitch, Edmund (1977) "The Nature and Function of the Patent System," Journal of Law and Economics 20: 265-290.

Landes, William and Richard Posner (1989) "An Economic Analysis of Copyright Law," Journal of Legal Studies 18: 325-363.

Miceli, Thomas, Henry Munneke, C.F. Sirmans, and Geoffrey Turnbull (2002) "Title Systems and Land Values," Journal of Law and Economics 45: 565-582.

Netter, Jeffry, Philip Hersch, and William Manson (1986) "An Economic Analysis of Adverse Possession," International Review of Law and Economics 6: 217-227.

Shick, Blair and Irving Plotkin (1978) Torrens in the United States: A Legal and Economic History and Analysis of American Land Registration Systems, Lexington, MA: Lexington Books. 